\title{
Peter's Paradigm and Pandemic Preparedness
}

\author{
Maryna C. Eichelberger
}

$\mathbf{P}$ ETER Doherty and Rolf Zinkernagel's discovery of how the body's immune system distinguishes virusinfected cells from normal cells is an essential element to curbing influenza infection and preventing severe disease. The recognition that $\mathrm{CD} 8+\mathrm{T}$ cells kill virus-infected cells by engaging with an "altered self"' (20), a complex of self major histocompatibility complex (MHC) molecule and the foreign antigen, enabled others to identify peptides of conserved influenza proteins as the primary targets of these killer cells $(12,17)$, providing a mechanism to explain protection against influenza $\mathrm{A} / \mathrm{H} 1 \mathrm{~N} 1$ (or other subtypes) after influenza A/H3N2 infection. Vaccines that target the induction of $\mathrm{CD} 8+\mathrm{T}$ cells and heterosubtypic immunity have, therefore, become an important strategy in the development of universal vaccines capable of broad protection and preventing severe disease during a pandemic $(9,3)$.

During my postdoctoral training in the Doherty laboratory at St. Jude Children's Research Hospital, we investigated several aspects of CD8+ T cell immunity. "Tea time" each morning in the old St Jude cafeteria is where ideas were mulled and experimental plans developed. The ideas were big, leaving lots of room for alternatives and testable hypotheses. We discussed how the immune response was initiated and argued about whether antigen persisted. Conversations continued throughout the day, with Peter always available to answer questions or discuss a problem. Peter's love for learning, openness to sharing ideas, and generosity in spending time with his staff in discussions not only of work but also life, provided a foundation for my career period. His example has been a model that I still try to follow and encourage others to aspire to.

We worked as a team in the Doherty laboratory; it was common for us to contribute to one another's experiments even if only to infect mice or harvest lymph nodes. In Peter's laboratory there were many opportunities to collaborate with molecular immunologists who were creating knockout or transgenic mice; an incredible time to show the in vivo function of single genes and to demonstrate the contribution of CD8+ T cells to influenza immunity. These opportunities to collaborate and Peter's amazing ability to communicate clearly provided me with a good number of quality publications $(2,4-8,18)$ that advanced my career.

Although most questions during my time working with Peter were targeted at understanding specific immune mecha- nisms, some of his work was translational, including several projects to identify and understand the human $\mathrm{T}$ cell response to viruses. From this came my interest to apply paradigms established in the laboratory to the human immune response, and for that reason, I joined the Center for Immunization Research at Johns Hopkins School of Public Health.

The first DNA vaccine trial, a naked plasmid expressing hemagglutinin (HA), was conducted soon after I arrived at Hopkins. My group was responsible for establishing tests to measure antibody and $\mathrm{T}$ cell responses. Unfortunately, the vaccine was not immunogenic at any of the doses tested; the antibody responses were undetectable, and $\mathrm{T}$ cell responses were negligible (unpublished). Since HA does not have well-characterized class I human leukocyte antigen (HLA)restricted epitopes, this study missed an opportunity to examine the ability of this novel vaccine to induce CD8+ T cell responses. DNA vaccines can indeed activate CD8+ T cells; a later DNA vaccine expressing a known target of human $\mathrm{CD} 8+\mathrm{T}$ cells nucleoprotein (NP) increased the number of $\gamma-$ interferon-producing $\mathrm{T}$ cells (16).

Unfortunately, many prelicensure clinical studies have shortcomings due to designs that do not consider findings from basic research. This may include discoveries related to vaccine immunogenicity or improvements that have been made to measure the immune response. Although research in mice should not be used as a substitute for human studies, incorporation of lessons learnt from mouse studies will improve the chance of success of a universal vaccine. For example, vaccines that target the induction of cytotoxic $\mathrm{T}$ cells should be formulated or designed to express a known $\mathrm{T}$ cell target antigen in dendritic cells or to allow cross-presentation. This is easily achieved by live viruses, recombinant vectors that express the targeted antigen, or messenger RNA vaccines, whereas inactivated or peptide vaccines require the use of delivery vehicles such as liposomes, or adjuvants to deposit the antigen appropriately.

The long history of studies by the Doherty laboratory and others demonstrating protection against influenza by $\mathrm{T}$ cell responses is finally being followed by clinical trials addressing that form of protection $(9,11)$. When human vaccine studies are planned, they should also consider findings from other clinical or epidemiologic studies. Despite strong evidence from studies conducted during the 1968 influenza

Division of Biological Standards and Quality Control, Office of Compliance and Biologics Quality, Center for Biologics Evaluation and Research, U.S. Food and Drug Administration, Bethesda, Maryland.

(c) Maryna C. Eichelberger, 2020; Published by Mary Ann Liebert, Inc. This Open Access article is distributed under the terms of the Creative Commons Attribution Noncommercial License (http://creativecommons.org/licenses/by-nc/4.0/) which permits any noncommercial use, distribution, and reproduction in any medium, provided the original author(s) and the source are cited. 
pandemic that antibodies to neuraminidase (NA) contribute to immunity against influenza (14), responses to NA have only recently been considered more routinely as a secondary immunogenicity end point.

NA inhibiting antibodies do not prevent infection but limit virus release from infected cells, resulting in "infectionpermissive" immunity $(13,1)$. It is highly likely that NAspecific antibodies also provide a frontline defense against influenza infection by preventing virus release from mucins, thereby reducing the number of infectious particles that are available to infect mucosal epithelial cells. Although we have a good understanding of the mechanism of NA-specific antibody action, clinical studies of most vaccines containing both HA and NA are designed in such a way that they cannot evaluate the contribution of NA immunity. For example, vaccine efficacy studies routinely use PCR-confirmed influenza as an end point. Considering NA immunity does not prevent infection but rather reduces disease by limiting. Virus spread, the contribution of NA immunity would require clinical measures of illness severity or duration of virus replication.

Test negative postlicensure observational studies are typically used to evaluate influenza vaccine effectiveness. In these studies, all subjects have symptoms of acute respiratory illness (i.e., influenza-like illness); the vaccine status of subjects positive for influenza by PCR testing is compared with the status of subjects who had a negative PCR test result. This type of study is very different from earlier observational studies of vaccine effectiveness in which cases were patients with influenza-like illness and controls were individuals without symptoms. With an understanding that NA immunity does not prevent infection but reduces clinical signs of disease, there is a good chance that the apparent poor effectiveness reported from studies using a test negative design may be the result of not counting individuals with subclinical or mild disease as benefiting from vaccination. The same issue applies to $\mathrm{T}$ cell vaccines.

In my opinion, a universal vaccine that targets $\mathrm{CD} 8+\mathrm{T}$ cells may be somewhat effective when CD8+ T cell memory is established in lymph nodes; however, there is a delay when the $\mathrm{T}$ cells are recalled to the site of infection (10). Therefore, the most effective vaccine may be one that induces local $\mathrm{T}$ cell immunity and results in memory $\mathrm{T}$ cells in the lungs. The benefit of having such CD8+ T cell memory located in the lungs in reducing virus load and recovery from infection is evident in a mouse model (19). Vaccines that target the induction of local immunity would need to be administered intranasally. This idea is verified by the rapid and robust protection observed in mice that were immunized with universal vaccine candidates intranasally (15).

Although animal studies can demonstrate that influenzaspecific CD8+ T cells have been induced and are present in the nasal or bronchial-associated lymphoid tissue or lungs, this would be difficult to evaluate during a human vaccine study. Evaluation of the benefit of vaccination is also difficult; as for $\mathrm{NA}$, influenza-specific cytolytic $\mathrm{T}$ cells do not protect from infection and, therefore, clinical benefit such as shortened duration of infection or reduced signs of disease would need to be demonstrated by daily monitoring of clinical signs and samples collected at several time points to determine virus titer or duration of infection. This is not possible to achieve in a typical observational study of vaccine efficacy.
Clinical challenge studies may be essential to establish overall benefit NA or CD8+ T cell-inducing vaccines in reducing symptoms and/or duration of influenza-like illness, and some such studies have been carried out. Although CD8+ T cell immunity may have minimal impact on seasonal influenza in a background of robust antibody responses to vaccines well matched to the virus, it is likely to be critical during a pandemic or an outbreak of an unexpected strain.

Given the current emphasis and need for development of a universal influenza vaccine, it would serve funding bodies and regulators well to make sure Peter's discoveries are considered in the development of universal influenza vaccines that target induction of CD8+ T cell responses. This type of vaccine could save millions of lives during a pandemic.

\section{Author Disclaimer}

My comments are an informal communication and represent my own best judgment. These comments do not bind or obligate the Food and Drug Administration.

\section{Author Disclosure Statement}

No competing financial interests exist.

\section{References}

1. Couch RB, Kasel JA, Gerin JL, Schulman JL, and Kilbourne ED. Induction of partial immunity to influenza by a neuraminidase-specific vaccine. J Infect Dis 1974;129:411420.

2. Deckhut AM, Allan W, McMickle A, et al. Prominent usage of $\mathrm{V}$ beta $8.3 \mathrm{~T}$ cells in the $\mathrm{H}-2 \mathrm{Db}$-restricted response to an influenza A virus nucleoprotein epitope. J Immunol 1993;151:2658-2666.

3. Dutton RW, Swain SL, and Woodland DL. Vaccines against pandemic influenza. Viral Immunol 2007;20:326-327.

4. Eichelberger M, Allan W, Carding SR, Bottomly K, and Doherty PC. Activation status of the CD4-8-gamma delta-T cells recovered from mice with influenza pneumonia. J Immunol 1991;147:2069-2074.

5. Eichelberger M, Allan W, Zijlstra M, Jaenisch R, and Doherty PC. Clearance of influenza virus respiratory infection in mice lacking class I major histocompatibility complex-restricted CD8+ T cells. J Exp Med 1991;174: 875-880.

6. Eichelberger M, and Doherty PC. Gamma delta T cells from influenza-infected mice develop a natural killer cell phenotype following culture. Cell Immunol 1994;159:94-102.

7. Eichelberger M, McMickle A, Blackman M, et al. Functional analysis of the TCR alpha- beta+ cells that accumulate in the pneumonic lung of influenza virus-infected TCR-alpha $^{-1-}$ mice. J Immunol 1995;154:1569-1576.

8. Eichelberger MC, Wang ML, Allan W, Webster RG, and Doherty PC. Influenza virus RNA in the lung and lymphoid tissue of immunologically intact and CD4-depleted mice. J Gen Virol 1991;72(Pt. 7):1695-1698.

9. Epstein SL. Universal influenza vaccines: progress in achieving broad cross-protection in vivo. Am J Epidemiol 2018;187:2603-2614.

10. Flynn KJ, Belz GT, Altman JD, et al. Virus-specific CD8+ $\mathrm{T}$ cells in primary and secondary influenza pneumonia. Immunity 1998;8:683-691.

11. Gilbert SC. Advances in the development of universal influenza vaccines. Influenza Other Respir Viruses 2013;7: $750-758$. 
12. Gotch F, Rothbard J, Howland K, Townsend A, and McMichael A. Cytotoxic T lymphocytes recognize a fragment of influenza virus matrix protein in association with HLA-A2. Nature 1987;326:881-882.

13. Kilbourne ED. Comparative efficacy of neuraminidasespecific and conventional influenza virus vaccines in induction of antibody to neuraminidase in humans. J Infect Dis 1976; 134:384-394.

14. Murphy BR, Kasel JA, and Chanock RM. Association of serum anti-neuraminidase antibody with resistance to influenza in man. N Engl J Med 1972;286:1329-1332.

15. Price GE, Soboleski MR, Lo CY, et al. Single-dose mucosal immunization with a candidate universal influenza vaccine provides rapid protection from virulent $\mathrm{H} 5 \mathrm{~N} 1$, H3N2 and H1N1 viruses. PLoS One 2010;5:e13162.

16. Smith LR, Wloch MK, Ye M, et al. Phase 1 clinical trials of the safety and immunogenicity of adjuvanted plasmid DNA vaccines encoding influenza A virus H5 hemagglutinin. Vaccine 2010;28:2565-2572.

17. Townsend AR, Rothbard J, Gotch FM, et al. The epitopes of influenza nucleoprotein recognized by cytotoxic $\mathrm{T}$ lymphocytes can be defined with short synthetic peptides. Cell 1986;44:959-968.
18. Van Kaer L, Ashton-Rickardt PG, Eichelberger M, et al. Altered peptidase and viral-specific $\mathrm{T}$ cell response in LMP2 mutant mice. Immunity 1994;1:533-541.

19. Wiley JA, Hogan RJ, Woodland DL, and Harmsen AG. Antigen-specific CD8(+) T cells persist in the upper respiratory tract following influenza virus infection. J Immunol 2001;167:3293-3299.

20. Zinkernagel RM, and Doherty PC. Immunological surveillance against altered self components by sensitised $\mathrm{T}$ lymphocytes in lymphocytic choriomeningitis. Nature 1974;251:547-548.

Address correspondence to: Dr. Maryna C. Eichelberger Division of Biological Standards and Quality Control Office of Compliance and Biologics Quality Center for Biologics Evaluation and Research U.S. Food and Drug Administration 8800 Rockville Pike Bethesda, MD 20982

E-mail: maryna.eichelberger@fda.hhs.gov 